\title{
Regulation of differential expression of platelet-derived growth factor $\alpha$ - and $\beta$-receptor mRNA in normal and malignant human mesothelial cell lines
}

\author{
Anthonie W. Langerak * , Carin A.J. van der Linden-van Beurden, Marjan A. Versnel \\ Department of Immunology, Erasmus University, P.O. Box 1738, 3000 DR Rotterdam, The Netherlands
}

Received 14 June 1995; revised 8 September 1995; accepted 20 September 1995

\begin{abstract}
In earlier studies we showed that the expression patterns of platelet-derived growth factor (PDGF) $\alpha$ - and $\beta$-receptors differ between normal and malignant mesothelial cell lines. Normal mesothelial cells predominantly express PDGF $\alpha$-receptor mRNA and protein, whereas most malignant mesothelioma cell lines produce PDGF $\beta$-receptor mRNA and protein. In this paper we studied regulation of this differential PDGF receptor mRNA expression. Such an analysis is of importance in view of the suggested PDGF autocrine activity involving the PDGF $\beta$-receptor in mesothelioma cells. The results obtained in this study demonstrate that malignant mesothelioma cell lines are not only capable of PDGF $\beta$-receptor transcription but of $\alpha$-receptor transcription as well, as evidenced from run off analysis and RT-PCR using $\alpha$-receptor specific primers. However, the fact that PDGF $\alpha$-receptor mRNA could not be detected by Northern blot analysis, even after cycloheximide treatment, suggests a difference in steady-state PDGF $\alpha$-receptor mRNA expression levels between normal and malignant mesothelial cell lines, which is likely to be caused by a post-transcriptional mechanism. In normal mesothelial cells a half-life of more than $6 \mathrm{~h}$ was observed for PDGF $\alpha$-receptor mRNA. In the majority of malignant mesothelioma cell lines clear PDGF $\beta$-receptor mRNA expression was seen. The half-life of the PDGF $\beta$-receptor transcript was at least $6 \mathrm{~h}$ in these cells. In contrast, hardly any PDGF $\beta$-receptor transcription was observed in run off assays in normal mesothelial cells, suggesting that differences in $\beta$-receptor transcriptional initiation most probably account for the inability to clearly detect PDGF $\beta$-receptor transcripts in these cells. Transforming growth factor $\beta-1$ (TGF- $\beta 1$ ), which is being produced in active form by mesothelial cells was evaluated for its potential role in regulation of the differential PDGF receptor expression in these cells. Stimulation with TGF- $\beta 1$ revealed decreased PDGF $\alpha$-receptor mRNA expression in normal mesothelial cells. The effect on PDGF $\beta$-receptor mRNA in the malignant mesothelioma cell lines was variable. Although the TGF- $\beta 1$ effect cannot entirely explain the differential PDGF receptor expression pattern, TGF- $\beta 1$ may nevertheless play a role in downregulation of an (already) low PDGF $\alpha$-receptor mRNA level in malignant mesothelioma cell lines.
\end{abstract}

Keywords: Platelet-derived growth factor $\alpha$-receptor; Platelet-derived growth factor $\beta$-receptor; Human mesothelial cell line; Malignant mesothelioma

\section{Introduction}

Platelet-derived growth factor (PDGF) is a mitogenic factor for cells of mesenchymal origin [15]. It is composed of two disulfide-bonded polypeptides, that are encoded by

\footnotetext{
Abbreviations: PDGF, platelet-derived growth factor; TGF- $\beta$, transforming growth factor $\beta$; EGF, epidermal growth factor; $H C$, hydrocortisone; FCS, fetal calf serum; CHX, cycloheximide; Act D, actinomycin D; GAPDH, glyceraldehyde-3-phosphate dehydrogenase; RT-PCR, reverse transcription polymerase chain reaction.

* Corresponding author. Fax: +31 10 4367601; e-mail: langerak@immu.fgg.eur.nl.
}

the distinct, but structurally related, PDGF A-chain and B-chain genes [6]. Homodimeric (AA and $\mathrm{BB}$ ) as well as heterodimeric $(\mathrm{AB})$ forms of PDGF have been observed. In addition, two homologous PDGF receptor subtypes have been described, the PDGF $\alpha$-receptor and PDGF $\beta$-receptor [14]. These two receptors show different affinities for the various dimeric PDGF forms. PDGF $\alpha$-receptors bind all PDGF isoforms (AA, AB, and BB) with high affinity, whereas PDGF $\beta$-receptors only show high affinity binding of PDGF-BB [26]. Ligand binding results in receptor dimerization and subsequent activation through cross-phosphorylation on tyrosine residues [18].

PDGF and PDGF receptors, expressed by various cell types like platelets, macrophages and cytotrophoblasts (for 
a review, see [25]) play a role in, e.g., wound healing and developmental processes. Furthermore, PDGF has been suggested to play a role in several tumour types as well (for a review, see [24,36]). Evidence for autocrine activity of PDGF has been presented in glioblastoma and astrocytoma cell lines $[27,30]$. In view of the involvement of PDGF and PDGF receptors in several physiological and pathophysiological processes, transcriptional regulation of PDGF chains and receptors is an important topic to study. Transcriptional regulation constitutes the first regulatory level of the biological action of PDGF as it determines the availability of ligands and signal-transducing receptors. Although studies on regulatory elements involved in transcription of the PDGF A-chain and B-chain genes have been performed in many cell types (for a recent review, see [17]), similar reports on PDGF receptor elements have been limited so far. Recently, studies on the promoter and upstream regulatory elements of the murine PDGF $\alpha$-receptor [35] and PDGF $\beta$-receptor [3] and the human PDGF $\alpha$-receptor [1] have been published.

Human malignant mesothelioma is a tumour of mesodermally derived tissues that is predominantly observed in the pleura. Based on in vitro and in vivo expression data, PDGF was suggested to play a role in the tumorigenesis of malignant mesothelioma $[20,31,33]$. In summary, malignant mesothelioma cells were found to express PDGF A-chain and B-chain mRNA at high levels, whereas normal mesothelial cells only expressed low levels of PDGF A-chain mRNA. Furthermore, expression of PDGF $\alpha$-receptor mRNA and protein was demonstrated in non-malignant mesothelial cells, whereas PDGF $\beta$-receptor transcripts and proteins were observed in the majority of malignant mesothelioma cells. Membrane-bound PDGF $\alpha$-receptor proteins were also found to be expressed by the latter [20]. In our normal and malignant mesothelial cell lines we previously analyzed regulation of PDGF A-chain and B-chain transcription ([19] and unpublished work). We now report on the regulation of the differential PDGF receptor mRNA expression in normal and malignant mesothelial cell lines, as insight into regulation of PDGF receptors in mesothelioma cells is relevant in view of the possible PDGF-driven autocrine loop in these cells. Direct evidence for such an autocrine loop should be obtained in future studies by introduction of, e.g., dominant-negative receptors [29] or dominant-negative ligands $[27,30]$. It has been shown in several studies that mRNA expression of PDGF chains and PDGF receptors is regulated by, e.g., acidic fibroblast growth factor and interleukin-1 $[23,37,38]$. Transforming growth factor- $\beta$ (TGF- $\beta$ ) is probably one of the most extensively studied regulators of PDGF receptor expression. TGF- $\beta$ stimulation has been shown to result in downregulation of PDGF $\alpha$-receptor mRNA in, e.g., fibroblasts and smooth muscle cells [4,22], whereas upregulation of PDGF $\beta$-receptor messenger levels was seen in smooth muscle and mesangial cells $[13,16]$. As active TGF- $\beta$ has been shown to be endogenously produced by mesothelial and mesothelioma cells $[10,12,21]$, we evaluated whether TGF- $\beta$ may contribute to the differential expression of PDGF $\alpha$ - and $\beta$-receptors in mesothelial cell lines.

Collectively, the results show that PDGF $\alpha$ - and $\beta$-receptor expression are differentially regulated between normal and malignant mesothelial cells. The mechanisms that most probably account for this differential PDGF receptor expression are discussed. The obtained results indicate that the mesothelial cell lines may constitute an useful model system for future studies on regulation of PDGF receptor expression and on the regulatory elements involved.

\section{Materials and methods}

\subsection{Cell lines and growth conditions}

Experiments were performed using the human malignant mesothelioma cell lines Mero-14, Mero-25, Mero-41, Mero-48c, Mero-72, Mero-82, Mero-84, and Mero-95 and the normal human mesothelial cell lines NM-9, NM-12, NM-21, NM-23, and NM-25 [20,32]. The cell lines were routinely cultured in Ham's F10 medium (Gibco, Paisley, UK) with $15 \%$ fetal calf serum [32]. Epidermal growth factor (EGF; Collaborative Research, Lexington, MA, USA; $10 \mathrm{ng} / \mathrm{ml}$ ) and hydrocortisone ( $\mathrm{HC} ; 0.4 \mu \mathrm{g} / \mathrm{ml}$ ) were added to the culture medium of normal mesothelial cells. In some experiments cells were exposed to cycloheximide (CHX; Sigma, St. Louis, MO, USA) at a concentration of $10 \mu \mathrm{g} / \mathrm{ml}$ medium for $2 \mathrm{~h}$ or to actinomycin D (Act D; Merck Sharp \& Dohme, Rahway, NJ, USA) at a concentration of $5 \mu \mathrm{g} / \mathrm{ml}$ medium for $1-6 \mathrm{~h}$.

Prior to TGF- $\beta 1$ treatment, cells were cultured under serumfree conditions in Ham's F10 medium (+EGF/HC for normal cells) supplemented with $0.1 \mathrm{mg} / \mathrm{ml} \mathrm{BSA}$ (Sigma), $10 \mu \mathrm{g} / \mathrm{ml}$ human transferrin (Behringwerke, Marburg, Germany), $10 \mu \mathrm{g} / \mathrm{ml}$ insulin (Sigma), and 50 nM sodium selenite (Merck, Darmstadt, Germany) for 24 h. Subsequent stimulation with human TGF- $\beta 1(2 \mathrm{ng} / \mathrm{ml}$; $24 \mathrm{~h}$; R\&D, Abingdon, UK) was performed in this serum-free medium as well.

\subsection{Probes}

For hybridization of Northern blots the $1.5 \mathrm{~kb} E c o \mathrm{RI}$ (extracellular) PDGF $\alpha$-receptor [8], the $1.7 \mathrm{~kb} E c o \mathrm{RI}$ $H$ indIII (extracellular) PDGF $\beta$-receptor [7], and the $0.7 \mathrm{~kb}$ EcoRI-PstI GAPDH [5] cDNA fragments were used as probes. For nuclear run off analysis the same extracellular PDGF $\alpha$-receptor and $\beta$-receptor fragments $[7,8]$ as well as the $1.25 \mathrm{~kb} P$ st I $\beta$-actin fragment from pAct [9] were all subcloned in the multicloning site of pUC and subsequently spotted onto nitrocellulose filters prior to hybridization. 


\subsection{Northern and Southern blot analyses}

RNA isolation, Northern blotting and subsequent hybridization were performed as described elsewhere [19]. Isolation of chromosomal DNA and transfer to Hybond-N (Amersham, UK) membranes were performed according to standard procedures. Hybridization and autoradiography were described previously [31].

\subsection{Nuclear run off assay}

Isolation of nuclei, in vitro labeling of nuclear RNA and hybridization were described elsewhere [19].

\subsection{RT-PCR analysis}

For reverse transcription (RT) $1 \mu \mathrm{g}$ total RNA was denatured at $65^{\circ} \mathrm{C}$ for $10 \mathrm{~min}$ and mixed with $10 \mu \mathrm{g} / \mathrm{ml}$ oligo(dT) ${ }_{15}$ (Pharmacia, Uppsala, Sweden), $2.5 A_{260} / \mathrm{ml}$ $(\mathrm{dN})_{6}$ (Pharmacia), avian myoblastoma virus (AMV) RT buffer $(50 \mathrm{mM}$ Tris- $\mathrm{HCl}, \mathrm{pH} 8.3 ; 50 \mathrm{mM} \mathrm{KCl} ; 10 \mathrm{mM}$ $\mathrm{MgCl}_{2} ; 1 \mathrm{mM}$ dithiothreitol; $1 \mathrm{mM}$ EDTA; $10 \mu \mathrm{g} / \mathrm{ml}$ bovine serum albumin), $1 \mathrm{mM}$ dNTPs, $1 \mathrm{mM}$ spermidine$\mathrm{HCl}$ (Sigma), 40 U RNAsin (Promega, Madison, WI, USA), and $5 \mathrm{U}$ AMV RTase (Promega) and incubated for $55 \mathrm{~min}$ at $39^{\circ} \mathrm{C}$. For amplification of PDGF $\alpha$-receptor sequences cDNA was mixed with Taq buffer $(10 \mathrm{mM}$ Tris- $\mathrm{HCl}, \mathrm{pH} 8.3 ; 50 \mathrm{mM} \mathrm{KCl} ; 1.5 \mathrm{mM} \mathrm{MgCl}_{2} ; 0.01 \%$ $(\mathrm{m} / \mathrm{v})$ gelatin), $0.2 \mathrm{mM}$ dNTPs, 20 pmol sense primer $\alpha$ R-7 (5'-CTGGAAGAAATCAAAGTCCCATCC-3'; bp 909-932 in the extracellular domain, according to the sequence in [8]), $20 \mathrm{pmol}$ antisense primer $\alpha \mathrm{R}-8\left(5^{\prime}\right.$ TGAGCCATGGTGATCATCGACC-3'; bp 1388-1409 in the extracellular domain), and 1 U Taq polymerass. (Perkin-Elmer Cetus, Norwalk, CT, USA). Forty cycles of $30 \mathrm{~s}$ at $94^{\circ} \mathrm{C}, 30 \mathrm{~s}$ at $65^{\circ} \mathrm{C}$, and $30 \mathrm{~s}$ at $72^{\circ} \mathrm{C}$ were performed.
The PDGF $\alpha$-receptor cDNA clone pSV7d15EB and a full-length PDGF $\beta$-receptor cDNA clone were used as positive and negative controls, respectively $[7,8]$. No amplified products were seen using these primers on chromosomal DNA and non-reverse transcribed RNA. All samples were checked for the amount of analyzable cDNA using specific HPRT gene primers (forty cycles of $30 \mathrm{~s}$ at $94^{\circ} \mathrm{C}$, $30 \mathrm{~s}$ at $55^{\circ} \mathrm{C}$, and $1 \mathrm{~min}$ at $72^{\circ} \mathrm{C}$ ). Ethidium bromide analysis and hybridization of filters with amplified PCR products were performed as described previously [19]. PDGF $\alpha$-receptor-specific oligo $\alpha$ R-3A (5'-TCACTGAGATCACCACTGATGTGG-3'; bp 1207-1230) was used as probe for hybridization.

\section{Results}

\subsection{Differential regulation of PDGF $\alpha$ - and $\beta$-receptor $m R N A$ expression in mesothelial cell lines}

As normal and malignant mesothelial cell lines display a differential PDGF receptor mRNA expression pattern and as there are no indications for consistent cytogenetic and/or genomic aberrations, run off assays were performed to study the nuclear PDGF $\alpha$ - and $\beta$-receptor mRNA levels in these cell lines. Nuclear PDGF $\alpha$-receptor RNA could be demonstrated in both normal and malignant mesothelial cell lines (Table 1). In Fig. 1 this is shown for NM-9 and Mero-14 as representative examples. Nuclear PDGF $\beta$-receptor transcripts were only detectable in the malignant mesothelioma cell lines and hardly or not in the normal mesothelial cell lines tested (Fig. 1 and Table 1). All cell lines tested clearly expressed nuclear RNA of the constitutively transcribed $\beta$-actin gene.

Culturing of several normal and malignant mesothelial cells with the protein synthesis inhibitor cycloheximide

Table 1

Summary of data on PDGF $\alpha$-receptor and B-receptor mRNA detection in normal and malignant mesothelial cell lines under various experimental conditions

\begin{tabular}{|c|c|c|c|c|c|c|c|}
\hline \multirow[t]{2}{*}{ Cell line } & \multicolumn{4}{|c|}{ PDGF $\alpha$-receptor } & \multicolumn{3}{|c|}{ PDGF $\beta$-receptor } \\
\hline & $\begin{array}{l}\text { nuclear RNA } \\
\text { (run off assay) }\end{array}$ & $\begin{array}{l}\text { mRNA (CHX } \\
\text { treated samples) }\end{array}$ & $\begin{array}{l}\text { mRNA } \\
\text { (RT-PCR) }\end{array}$ & $\begin{array}{l}\text { mRNA half-life } \\
\text { (Act D treated } \\
\text { samples) }\end{array}$ & $\begin{array}{l}\text { nuclear RNA } \\
\text { (run off assay) }\end{array}$ & $\begin{array}{l}\text { mRNA (CHX } \\
\text { treated samples) }\end{array}$ & $\begin{array}{l}\text { mRNA half-life } \\
\text { (Act D treated } \\
\text { samples) }\end{array}$ \\
\hline NM-9 & + & + & + & $\min .4-6 h$ & - & - & $\begin{array}{l}\text { no mRNA } \\
\text { detectable }\end{array}$ \\
\hline NM-12 & + & + & $\mathrm{ND}$ & ND & - & - & ND \\
\hline NM-23 & ND & ND & + & $\mathrm{ND}$ & ND & ND & ND \\
\hline Mero-14 & + & - & $+1-$ & $\begin{array}{l}\text { no mRNA } \\
\text { detectable }\end{array}$ & + & + & $\min .4-6 h$ \\
\hline Mero-25 & + & - & $+1-$ & ND & $+1-$ & $+/-$ & $\mathrm{ND}$ \\
\hline Mero-41 & ND & - & $+1-$ & ND & + & + & ND \\
\hline Mero-48c & ND & - & $+1-$ & ND & + & + & ND \\
\hline Mero-82 & + & - & $+1-$ & $\begin{array}{l}\text { no mRNA } \\
\text { detectable }\end{array}$ & $+1-$ & $+/-$ & $\min .4-6 \mathrm{~h}$ \\
\hline Mero-84 & + & ND & ND & $\mathrm{ND}$ & + & ND & ND \\
\hline
\end{tabular}

ND: not determined. 


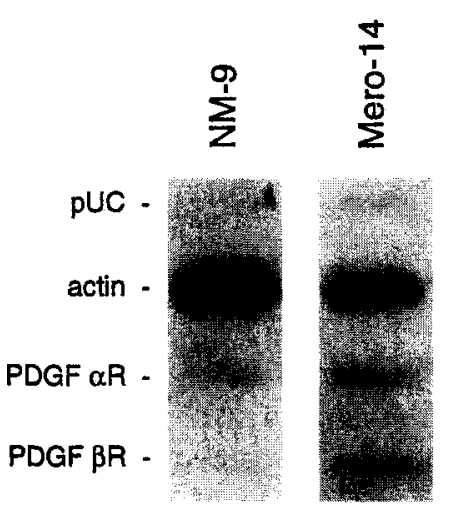

Fig. 1. Nuclear run off analysis using ${ }^{32} \mathrm{P}$-labeled nuclear RNA of normal mesothelial (NM-9) and malignant mesothelioma (Mero-14) cell lines. The nitrocellulose blots contained plasmids pUC, pUC plus actin, pUC plus PDGF $\alpha$-receptor, and pUC plus PDGF $\beta$-receptor.

(CHX; $10 \mu \mathrm{g} / \mathrm{ml}$ ) did not significantly affect the PDGF $\beta$-receptor mRNA levels in both cell types (Table 1). This is shown for NM-12 and Mero-14 in Fig. 2. PDGF $\beta$-receptor mRNA expression was hardly or not detectable in untreated as well as CHX-treated normal mesothelial cells. Furthermore, CHX treatment did not alter the differential expression of PDGF $\alpha$-receptor transcripts in normal and malignant mesothelial cell lines, as determined by Northern blot analysis (Fig. 2 and Table 1). In CHX-treated malignant mesothelioma cell lines no PDGF $\alpha$-receptor mRNA could be demonstrated. Moreover, the use of higher concentrations of CHX (20-30 $\mu \mathrm{g} / \mathrm{ml})$ still did not result in detectable PDGF $\alpha$-receptor expression in these cells (data not shown).

\subsection{Detection of PDGF $\alpha$-receptor mRNA by RT-PCR}

To obtain further evidence for PDGF $\alpha$-receptor gene expression in malignant mesothelioma cell lines, we performed RT-PCR analysis. Amplification of PDGF $\alpha$-receptor cDNA clone pSV7d15EB (used as positive control) with primers $\alpha \mathrm{R}-7$ and $\alpha \mathrm{R}-8$, located in the extracellular domain, resulted in a $501 \mathrm{bp}$ band. A fragment of similar size could also be amplified from cDNA of normal mesothelial cells (Fig. 3 and Table 1). In the majority of our malignant mesothelioma cell lines such a 501 bp band could be detected as well, although the intensity was generally much lower than in normal mesothelial cell lines (Fig. 3 and Table 1). However, distinct samples of a single malignant mesothelioma cell line were not always positive, further indicating low expression levels indeed. Since the PDGF $\alpha$ - and $\beta$-receptor sequences are quite homologous in many regions, cross-reactivity of the $\alpha \mathrm{R}-7$ and $\alpha \mathrm{R}-8$ primers with $\beta$-receptor sequences in these cells had to be excluded. Therefore, we checked the specificity of the PDGF $\alpha$-receptor primers in various ways. EcoRV digestion of the amplified fragments resulted in the expected 244 and 257 bp PDGF $\alpha$-receptor-cDNA fragments (data not shown), whereas hybridization with the $\alpha \mathrm{R}-3 \mathrm{~A}$ oligo further confirmed the PDGF $\alpha$-receptor origin of the amplified cDNA fragments (Fig. 3). Furthermore, the lack of amplification of the PDGF $\beta$-receptor cDNA construct with these primers excluded cross-reactivity with PDGF $\beta$-receptor sequences. Finally, genomic DNA, non-reverse transcribed RNA, and $\mathrm{H}_{2} \mathrm{O}$ controls were all negative. Despite the low expression levels, the results are thus in agreement with the data obtained in run off assays, indicating that malignant mesothelioma cells are in principle capable of producing PDGF $\alpha$-receptor mRNA as well.

\subsection{Stability of PDGF $\alpha$ - and $\beta$-receptor transcripts}

The stability of the PDGF $\alpha$ - and $\beta$-receptor transcripts was studied by Northern blot analysis in a few normal and malignant mesothelial cell lines (NM-9, Mero-14, Mero82), which were treated with actinomycin $D(A c t D)$ for different times. The PDGF $\alpha$-receptor and PDGF $\beta$-receptor mRNA levels remained relatively stable during a $4 \mathrm{~h}$ treatment with Act $D$, suggesting half-lives of at least $4 \mathrm{~h}$ (Table 1). In Fig. 4 this is shown for NM-9 and Mero-14.

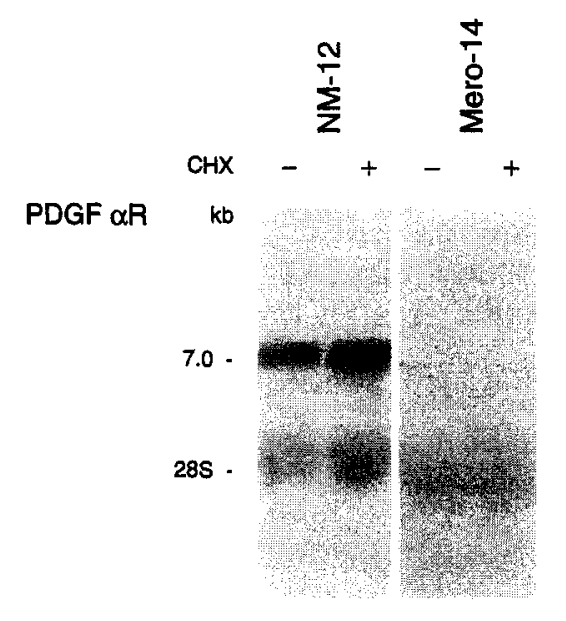

PDGF $\beta R$

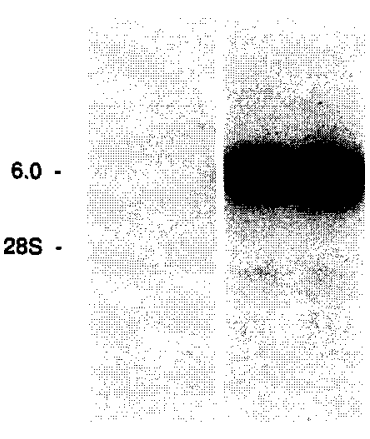

GAPDH

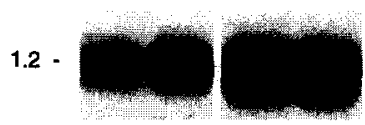

Fig. 2. Northern blot analysis of total RNA from normal mesothelial (NM-12) and malignant mesothelioma (Mero-14) cell lines. Total RNA $(25 \mu \mathrm{g})$ of cells cultured in the absence $(-)$ or presence $(+)$ of 10 $\mu \mathrm{g} / \mathrm{ml}$ cycloheximide (CHX) was blotted and hybridized to PDGF $\alpha$-receptor, PDGF $\beta$-receptor, and GAPDH probes. 


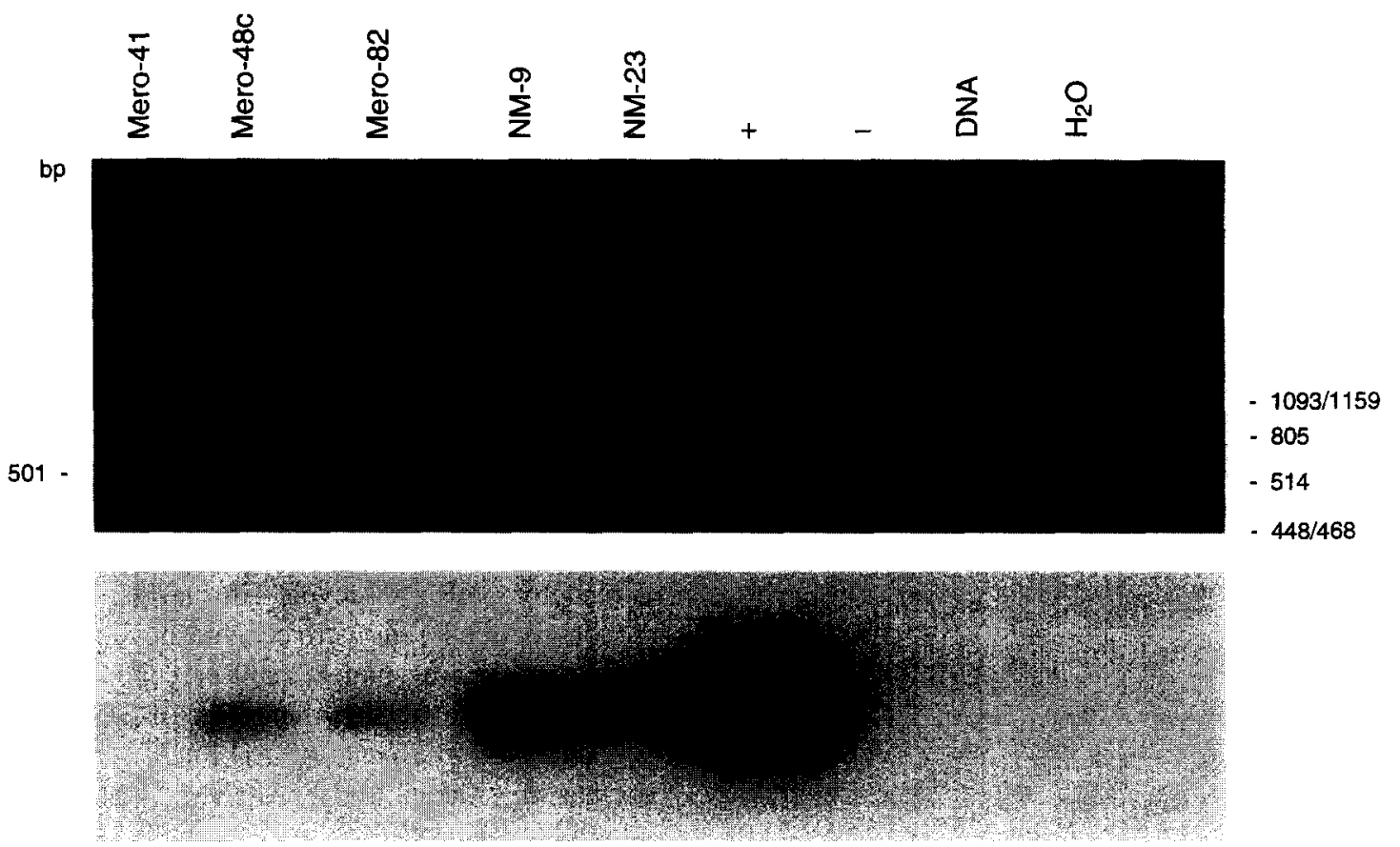

Fig. 3. Reverse-transcription PCR analysis of RNA from normal mesothelial (NM-9, NM-23) and malignant mesothelioma (Mero-41, Mero-48c, Mero-82) cell lines. Upper panel: ethidium bromide analysis of amplified products, using cDNA from PDGF $\alpha$-receptor clone pSV7d15EB as positive control ( + ). PDGF B-receptor cDNA was used to exclude cross-reactivity of the $\alpha$ R-7 and $\alpha$ R-8 primers (-). Genomic DNA and $\mathrm{H}_{2} \mathrm{O}$ were used as negative controls. Lower panel: after blotting the filter was hybridized to $\alpha$-receptor-specific oligo $\alpha \mathrm{R}-3 \mathrm{~A}$.

In fact both transcripts are rather stable, as even prolonged exposure $(6 \mathrm{~h})$ to Act $\mathrm{D}$ did not result in significant decreases in $\alpha$-receptor levels in normal mesothelial cell lines or in $\beta$-receptor levels in mesothelioma cell lines (data not shown). Further support for the high PDGF receptor mRNA stability in these cells came from the observation that at the utilized Act D concentration the PDGF A-chain messenger half-life of these cells was 2 to $3 \mathrm{~h}$, which is in agreement with our earlier findings [19]. Unfortunately, the stability of PDGF $\alpha$-receptor transcripts in malignant mesothelioma cell lines could not be determined due to the inability to detect these messengers in

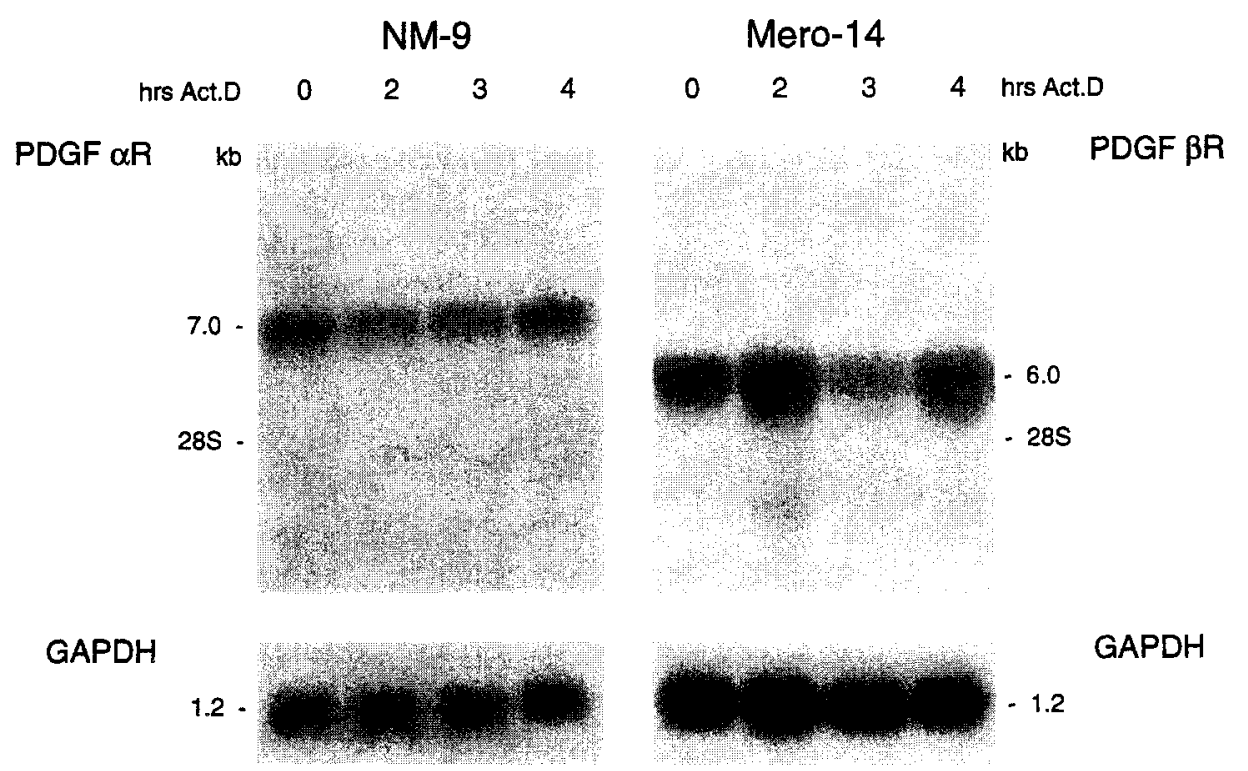

Fig. 4. Northern blot analysis of total RNA from normal mesothelial (NM-9) and malignant mesothelioma (Mero-14) cell lines. Total RNA (25 $\mu \mathrm{g}$ ) of NM-9 cells cultured in the presence of $5 \mu \mathrm{g} / \mathrm{ml}$ actinomycin D (Act D) for the indicated times was blotted and hybridized to PDGF $\alpha$-receptor and GAPDH probes. Similarly, total RNA of Mero-14 cells cultured with Act D, was hybridized to PDGF B-receptor and GAPDH probes. 
these cell lines by Northern blot analysis. RT-PCR of Act $D$-treated cells has not been performed because the quality of the RNA isolated from the Act D-treated cells was not constant enough for reliable determination of PDGF $\alpha$-receptor mRNA half-lives in these cells.
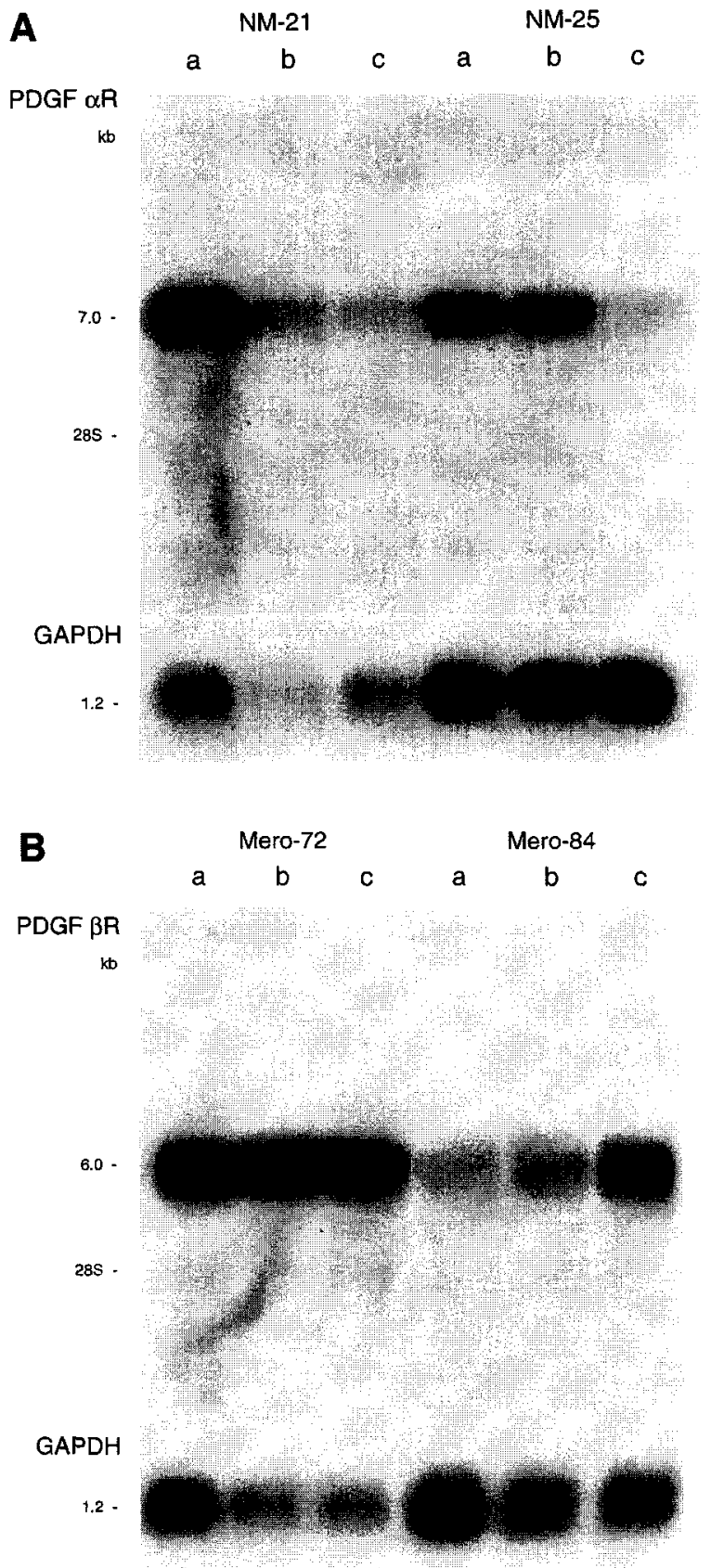

Fig. 5. Northern blot analysis of total RNA from normal mesothelial (NM-21, NM-25) (A) and malignant mesothelioma (Mero-72, Mero-84) (B) cell lines. Cells were either cultured without serum (lanes a), cultured without serum for another $24 \mathrm{~h}$. (lanes b) or cultured in the presence of 2 $\mathrm{ng} / \mathrm{ml}$ transforming growth factor- $\beta 1$ (TGF- $\beta 1)$ under serumfree conditions (lanes c). Total RNA (25 $\mu \mathrm{g}$ ) was blotted and hybridized to PDGF $\alpha$-receptor (A) and PDGF $\beta$-receptor (B) probes. GAPDH hybridization was done for control.

\subsection{Differential effects of TGF- $\beta 1$ on PDGF $\alpha$ - and $\beta$-receptor mRNA levels}

To further identify which factor(s) may be involved in regulation of the differential PDGF rceptor expression between normal and malignant mesothelial cells, we evaluated the possible contribution of TGF- $\beta 1$. TGF- $\beta 1$ is one of the most extensively studied regulators of PDGF receptor expression and is known to be produced in an active form by mesothelial cells. In a pilot experiment, that was designed to identify conditions for TGF- $\beta 1$ stimulation, maximal effects were seen under serumfree conditions using $2 \mathrm{ng} / \mathrm{ml}$ TGF- $\beta 1$ for $24 \mathrm{~h}$ (data not shown). Serumfree culture was found to slightly alter PDGF $\alpha$ - and $\beta$-receptor mRNA levels in normal and malignant mesothelial cells, respectively, but no significant induction of the otherwise undetectable receptor type was seen. Based on these results, the effect of TGF- $\beta 1$ stimulation was analyzed in a panel of cell lines. Serumfree culture of normal mesothelial cell lines (NM-21 and NM-25) for an additional $24 \mathrm{~h}$ resulted in slightly altered PDGF $\alpha$-receptor mRNA expression levels (Fig. 5A, lanes a, b). In parallel cultures addition of $2 \mathrm{ng} / \mathrm{ml}$ TGF- $\beta 1$ caused downregulation of $\alpha$-receptor messenger expression in these cell lines, as can be seen when comparing lanes $b$ and $c$. In malignant mesothelioma cell lines no PDGF- $\alpha$ receptor mRNA expression was seen under the conditions tested. The effect of serumfree culture and TGF- $\beta 1$ stimulation on PDGF $\beta$-receptor mRNA levels in the malignant mesothelioma cell lines tested, was variable. In two out of six (Mero-82, Mero-84) an increase in PDGF $\beta$-receptor level was seen after serum depletion, which was even further increased by TGF- $\beta 1$ stimulation (Fig. 5B, lanes b, c). In Mero-72 the level was slightly increased by serum depletion, but TGF- $\beta 1$ did not have a clear additional effect (Fig. 5B, lanes b, c). Of the other three cell lines tested, one did not demonstrate PDGF $\beta$-receptor mRNA expression under all conditions (Mero-95), whereas the other two showed rather low (Mero-25, Mero-41) expression levels that were hardly affected by serum removal or TGF- $\beta 1$ stimulation (data not shown). In normal mesothelial cell lines a weak enhancing effect was seen after serum removal.

\section{Discussion}

We previously reported on PDGF $\alpha$-receptor mRNA expression in normal mesothelial cells, whereas on Northern blots only PDGF $\beta$-receptor transcripts could be detected in nearly all malignant mesothelioma cell lines [33]. These differences are not likely to be caused by culturing, as has been described for fibroblasts and smooth muscle cells [28]. Addition of EGF and HC (added to normal mesothelial cells cultures) and serum removal just slightly modulated PDGF receptor mRNA levels in both normal 
and malignant mesothelial cell lines and, most importantly, did not cause induction of the otherwise undetectable PDGF receptor subunit ([34] and this study). Moreover, the differential PDGF receptor expression patterns were also seen in uncultured normal and malignant mesothelial cells [20]. Cytogenetic analysis did not demonstrate any consistent chromosomal aberration on chromosomes 4 ( $\alpha$-receptor) or 5 ( $\beta$-receptor) in the malignant mesothelioma cell lines [33]. Furthermore, in the present study no PDGF $\alpha$-receptor gene rearrangements or intragenic deletions were detected in the malignant mesothelioma cell lines by Southern blot analysis using EcoRI-digested DNA (data not shown). We therefore evaluated transcriptional and post-transcriptional regulation of the differential PDGF receptor mRNA pattern in mesothelial cells. We conclude that the absence of clear PDGF $\beta$-receptor mRNA levels in total RNA of normal mesothelial cell lines is probably caused by lack of transcription of this gene rather than by rapid decay of unstable messengers. In contrast, the absence of PDGF $\alpha$-receptor mRNA on Northern blots of malignant mesothelioma cell lines cannot be explained similarly. Several lines of evidence suggest that malignant mesothelioma cell lines are actually capable of transcribing the PDGF $\alpha$-receptor gene. By nuclear run off analysis as well as RT-PCR PDGF $\alpha$-receptor transcripts could be detected, although in the latter assay the expression level was rather low and variable as compared to normal mesothelial cells. Prolonged exposure of blots containing poly $(\mathrm{A})^{+}$RNA of malignant mesothelioma cell lines also showed a faint PDGF $\alpha$-receptor hybridization signal (data not shown). Furthermore, other investigators found PDGF $\alpha$-receptor transcripts in their malignant mesothelioma cell lines using the sensitive RNase protection analysis [11]. In line with all these findings we also observed membranebound PDGF $\alpha$-receptor proteins on malignant mesothelioma cells using immunostaining techniques [20]. Furthermore, in view of these data the earlier observed binding of radiolabeled ${ }^{125}$ I-PDGF-AA to malignant mesothelioma cell lines should not be interpreted as background binding, but rather as specific, though low, binding of PDGF-AA to PDGF $\alpha$-receptors on these cells [33]. Despite the demonstration of PDGF $\alpha$-receptor expression in malignant mesothelioma cell lines, it remains to be determined in future studies whether growth stimulation via PDGF $\alpha$-receptors is really of biological importance in these cells as well.

Being one of the best studied regulators of PDGF receptor expression and being produced in active form by both normal and malignant mesothelial cells, TGF- $\beta 1$ was evaluated for its putative contribution to the differential PDGF receptor expression in mesothelial cell lines. After stimulation with TGF- $\beta 1$, no induction of PDGF $\alpha$ - and $\beta$-receptor mRNA was seen in normal and malignant mesothelial cells, respectively. However, PDGF $\alpha$-receptor mRNA levels in normal mesothelial cells were found to be decreased by TGF- $\beta 1$, which is similar to what has been described for, e.g., smooth muscle cells and fibroblasts $[4,22]$. The effect of TGF- $\beta$ I on PDGF $\beta$-receptor expression in malignant mesothelioma cell lines was variable, which also fits in with data from other cell types, like smooth muscle and mesangial cells $[13,16,22]$. Taken together, the effect of TGF- $\beta 1$ stimulation is not likely to explain the differential PDGF receptor expression. Nevertheless, the low PDGF $\alpha$-receptor mRNA expression in malignant mesothelioma cell lines may well be (partly) the consequence of $\alpha$-receptor downregulation by endogenously produced TGF- $\beta 1$. However, the latter suggestion awaits further experimental proof. Recently, it has been shown that antisense messengers against TGF- $\beta 2$ and to a lesser extent against TGF- $\beta 1$, resulted in growth-inhibition of mesothelioma cells in vitro and in reduced tumorigenicity and increased T-lymphocyte infiltration in vivo [10] Together these results suggest an important role for TGF- $\beta$ in mesothelial carcinogenesis. The results described in this study indicate that modulation of PDGF receptor mRNA expression may be another effect of TGF- $\beta 1$ in (part of the) malignant mesothelioma cells.

The apparent inability to detect PDGF $\alpha$-receptor messengers in malignant mesothelioma cells by Northern blot analysis, is most probably due to rapid degradation, suggesting that the PDGF $\alpha$-receptor transcript is rather unstable in malignant mesothelioma cells. In contrast, the $\alpha$-receptor messenger in normal mesothelial cells is quite stable, with a half-life of at least $6 \mathrm{~h}$. As inhibition of protein synthesis did not seem to influence PDGF $\alpha$-receptor mRNA stability in malignant mesothelioma cells, labile degrading proteins are not likely to be involved. However, CHX-insensitive proteins may very well be responsible for the observed difference in stability. Alternatively, it may be that the absence of certain degradation-protecting proteins or the presence of mutations in $3^{\prime}$ untranslated sequences (UTS) cause differences in PDGF $\alpha$-receptor messenger stability between normal and malignant cells. AUUUA regions in the $3^{\prime}$ UTS have earlier been shown to play a role in stability of, e.g., GM-CSF transcripts [2]. It remains to be determined if any of these mechanisms accounts for the apparent difference in PDGF $\alpha$-receptor stability between normal and malignant mesothelial cells.

Recently there has been a report in which the murine PDGF $\beta$-receptor promoter was described [3]. Concerning the PDGF $\alpha$-receptor, a minimal promoter region of $93 \mathrm{bp}$ relative to the transcription start was identified, that functioned in a way that mirrored mouse tissue-specific PDGF $\alpha$-receptor expression [35]. Moreover, a similar though larger promoter region was identified in human Tera-2 cells [1]. It would be interesting to see whether this promoter region would be sufficient to drive PDGF $\alpha$-receptor transcription in mesothelial cells as well. Based on the earlier discussed differences and similarities in regulation of PDGF $\alpha$-receptor and $\beta$-receptor expression, normal and malignant mesothelial cell lines could be very helpful for characterization of promoter and upstream reg- 
ulatory elements of both PDGF receptor genes in human cells.

In conclusion, data on regulation of PDGF receptor expression collectively suggests that both PDGF $\alpha$ - and $\beta$-receptor transcripts can be expressed by malignant mesothelioma cell lines. However, there seems to be a difference in stability between PDGF $\alpha$ - and $\beta$-receptor transcripts. Moreover, $\alpha$-receptor processing in malignant mesothelioma cell lines seems to be different from that in normal mesothelial cell lines as well. Further identification of the mechanism behind this processing will therefore be a topic of future studies.

\section{Acknowledgements}

We thank Prof. dr. R. Benner for continuous support, Mr. T.M. van Os for help in preparation of figures and Mrs. P.C. Assems for secretarial assistance. The pSV7d15EB PDGF $\alpha$-receptor cDNA clone and the fulllength PDGF $\beta$-receptor cDNA clone were kindly provided by Dr. L. Claesson-Welsh and Dr. C.-H. Heldin. This study was supported by a grant from the Dutch Cancer Society.

\section{References}

[1] Afink, G.B., Nistér, M., Stassen, B.H.G.J., Joosten, P.H.L.J., Rademakers, P.J.H., Bongcam-Rudloff, E., Van Zoelen, E.J.J. and Mosselman, S. (1995) Oncogene 10, 1667-1672.

[2] Akashi, M., Shaw, G., Gross, M., Saito, M. and Koeffler, H.P. (1991) Blood 78, 2005-2012.

[3] Ballagi, A.E., Ishizaki, A., Nehlin, J.O. and Funa K. (1995) Biochem. Biophys. Res. Commun. 210, 165-173.

[4] Battegay, E.J., Raines, E.W., Seifert, R.A., Bowen-Pope, D.F. and Ross, R. (1990) Cell 63, 515-524.

[5] Benham, F.J., Hodgkinson, S. and Davies, K.E. (1984) EMBO J. 3, 2635-2640.

[6] Betsholtz, C., Johnsson, A., Heldin, C.-H., Westermark, B., Lind, P., Urdea, M.S., Eddy, R., Shows, T.B., Philpott, K., Mellor, A.L., Knott, T.J. and Scott, J. (1986) Nature 320, 695-699.

[7] Claesson-Welsh, L., Eriksson, A., Morén, A., Severinsson, L., Ek, B., Östman, A., Betsholtz, C. and Heldin, C.-H. (1988) Mol. Cell. Biol. 8, 3476-3486.

[8] Claesson-Welsh, L., Eriksson, A., Westermark, B. and Heldin, C.-H. (1989) Proc. Natl. Acad. Sci. USA 86, 4917-4921.

[9] Dodemont, H.J., Soriano, P., Quax, W.J., Ramaekers, F., Lenstra, J.A., Groenen, M.A., Bernardi, G. and Bloemendal, H. (1982) EMBO J. 1, 167-171.

[10] Fitzpatrick, D.R., Bielefeldt-Ohmann, H., Himbeck, R.P., Jarnicki, A.G., Marzo, A.L. and Robinson, B.W.S. (1994) Growth Fact. 11, $29-44$.

[11] Garlepp, M.J., Christmas, T.I., Manning, L.S., Mutsaers, S.E., Dench, J., Leong, C. and Robinson, B.W.S. (1993) Eur. Resp. Rev. 3, 189-191.

[12] Gerwin, B.I., Lechner, J.F., Reddel, R.R., Roberts, A.B., Robbins,
K.C., Gabrielson, E.W. and Harris, C.C. (1987) Cancer Res. 47, $6180-6184$.

[13] Haberstroh, U., Zahner, G., Disser, M., Thaiss, F., Wolf, G. and Stahl, R.A.K. (1993) Am. J. Physiol. 264, F199-F205.

[14] Heldin, C.-H., Bäckström, G., Östman, A., Hammacher, A., Rönnstrand, L., Rubin, K., Nistér, M. and Westermark, B. (1988) EMBO J. 7, 1387-1393.

[15] Heldin, C.-H. and Westermark, B. (1990) Cell Regul. 1, 555-566.

[16] Janat, M.F. and Liau, G. (1992) J. Cell. Physiol. 150, 232-242.

[17] Kaetzel, D.M., Coyne, D.W. and Fenstermaker, R.A. (1993) Biofactors 4, 71-81.

[18] Kelly, J.D., Haldeman, B.A., Grant, F.J., Murray, M.J., Seifert, R.A., Bowen-Pope, D.F., Cooper, J.A. and Kazlauskas, A. (1991) J. Biol. Chem. 266, 8987-8992.

[19] Langerak, A.W., Dirks, R.P.H. and Versnel, M.A. (1992) Eur. J. Biochem. 208, 589-596.

[20] Langerak, A.W., De Laat, P.A.J.M., Van der Linden-van Beurden, C.A.J., Delahaye, M., Van der Kwast Th.H., Hoogsteden, H.C., Benner, R. and Versnel, M.A. (1995) J. Pathol., in press.

[21] Maeda, J., Ueki, N., Ohkawa, T., Iwahashi, N., Nakano, T., Hada T. and Higashino, K. (1994) Clin. Exp. Immunol. 98, 319-322.

[22] Paulsson, Y., Karlsson, C., Heldin, C.-H. and Westermark, B. (1993) J. Cell. Physiol. 157, 97-103.

[23] Raines, E.W., Dower, S.K. and Ross, R. (1989) Science 243, 393-396.

[24] Raines, E.W., Bowen-Pope, D.F. and Ross, R. (1990) Peptide Growth Factors and their Receptors, Handbook in Experimental Pharmacology, Vol. 95, part 1, pp. 173-262, Springer, Heidelberg.

[25] Ross, R., Bowen-Pope, D.F. and Raines, E.W. (1990) Phil. Trans. R. Soc. Lond. 327, 155-169.

[26] Seifert, R.A., Hart, C.E., Phillips, P.E., Forstrom, J.W., Ross, R., Murray, M.J. and Bowen-Pope, D.F. (1989) J. Biol. Chem. 264, $8771-8778$

[27] Shamah, S.M., Stiles, C.D. and Guha, A. (1993) Mol. Cell. Biol. 13 , $7203-7212$.

[28] Terracio, L., Ronnstrand, L., Tingstrom, A., Rubin, K., ClaessonWelsh, L., Funa, K. and Heldin, C.-H. (1998) J. Cell Biol. 107, 1947-1957.

[29] Ueno, H., Escobedo, J.A. and Williams, L.T. (1993) J. Biol. Chem. 268, 22814-22819.

[30] Vassbotn, F.S., Östman, A., Langeland, N., Holmsen, H.A., Westermark, B., Heldin, C.-H. and Nistér, M. (1994) J. Cell. Physiol. 158, 381-389.

[31] Versnel, M.A., Hagemeijer, A., Bouts, M.J., Van der Kwast, Th.H. and Hoogsteden, H.C. (1988) Oncogene 2, 601-605.

[32] Versnel, M.A., Bouts, M.J., Hoogsteden, H.C., Van der Kwast, Th.H., Delahaye, M. and Hagemeijer, A. (1989) Int. J. Cancer 44, 256-260.

[33] Versnel, M.A., Claesson-Welsh, L., Hammacher, A., Bouts, M.J., Van der Kwast, Th.H., Eriksson, A., Willemsen, R., Weima, S.M., Hoogsteden, H.C., Hagemeijer, A. and Heldin, C.-H. (1991) Oncogene 6, 2005-2011.

[34] Versnel, M.A., Bouts, M.J., Langerak, A.W., Van der Kwast, Th.H. Hoogsteden, H.C., Hagemeijer, A. and Heldin, C.-H. (1992) Exp. Cell Res. 200, 83-88.

[35] Wang, C. and Stiles, C.D. (1994) Proc. Natl. Acad. Sci. USA 91 , $7061-7065$.

[36] Westermark, B. and Heldin, C.-H. (1991) Cancer Res. 51, 50875092.

[37] Winkles, J.A. and Gay, C.G. (1991) Biochem. Biophys. Res. Commun. 180, 519-524.

[38] Xie, J., Stroumza, J. and Graves, D.T. (1994) J. Immunol. 153, 378-383. 